\title{
Keeping up the Conversation on Culture: A Response to Robert Courchêne and Others
}

\author{
Jennifer Walsh-Marr
}

Robert Courchêne's 1996 article entitled "Teaching Canadian Culture: Teacher Preparation" sparked a conversation in the pages of the TESL Canada Journal that continues today. From advocating the teaching of significant historical events and icons to encouraging second-language learners to embrace cultural ambiguity, there is a wide spectrum of philosophies and approaches for English-as-anAdditional-Language (EAL) professionals to consider. This article attempts to summarize the discussion so far, to contextualize it in research frameworks, and to build on practical suggestions for teachers charged with teaching culture to their students.

L'article de Robert Courchêne daté de 1996 et intitulé « Teaching Canadian Culture: Teacher Preparation » a provoqué une conversation dans la Revue TESL Canada qui continue encore de nos jours. La gamme des philosophies et des approches pour l'enseignement de l'anglais langue additionnelle est vaste, allant de la recommandation d'enseigner les icônes et les évènements historiques importants à celle d'encourager les apprenants à adopter l'ambigüité culturelle. Cet article tente de résumer la discussion qui a eu lieu jusqu'ici, de la contextualiser dans des cadres de recherche et de prendre appui sur les suggestions pratiques pour les enseignants chargés d'enseigner la culture à leurs élèves.

\section{The Conversation Thus Far}

In establishing the context of his work, Courchêne (1996) claims: "culture is dynamic, rooted in a specific social context, subject to innumerable social forces" (p. 6) The social forces that determine EAL learners' identities, needs, and future contexts need to be taken into consideration when discussing culture and how, if at all, it is to be "taught." The dynamic nature of not only culture, but the lives of its participants is paramount to meaningful inquiry and growth for student and teacher alike.

Courchêne's article shows two major assumptions about students: (a) they have relocated to Canada semi-permanently and are invested in making this country their home, and (b) they are passive recipients ready to accept information about Canada to complete gaps in their knowledge. Courchêne's assumptions about culture are equally limiting: he idealizes countries with a "unified history" (p. 2) and suggests adapting Hirsch's (1987) United States 
cultural canon to a Canadian context. Courchêne would use this conservative, codified common knowledge as the basis for his "New Cultural Vision" (p. 7), an established paradigm that is "a synthesis of the past and the present, the old and the new" (p. 6).

Courchêne's (1996) inclusion of Morasse's (1995) and others' cultural exploratory work exhibits a willingness to explore students' impressions of cultural values and the behaviors that manifest these values, but by his own admission, this results in "place[ing] learners in the situation of the other" (p. 10). The tasks position newcomers" observations against "the true state of affairs to temper their judgments" (p. 9), implying that there is a clearly defined right answer and cultural code that the students do not or cannot possess and cannot interpret adequately without the assistance of an expert in Canadian culture. In "correcting" a learner's impression of an observation, Morasse and Courchêne both perpetuate the image of the student as an outsider who can gain access to Canadian culture not through observation and negotiation, but only through the acquisition of codified norms.

In developing Canadian cultural experts, Courchêne advocates for new teachers to "be trained to be more effective interpreters of cultural knowledge and, as a result, better prepared to help their students learn new cultural knowledge" (p. 10). This exhibits what Sauvé (1996) refers to as a "delivery mode" of education (p. 18), in which information needs to be simply given to the teacher to transmit to the learner. In her response to Courchêne, Sauvé challenges more than the epistemology of Courchêne's work; she questions his theoretical framework of culture, its underlying bias, and its limiting context. Sauve references Hall's (1993) layers of culture, where the first layer is deep within our unconscious, inaccessible to analysis or discussion. Such a position prompts the inevitable question of how to teach something that cannot be examined or properly understood. Sauvé (1997), despite her writing in Canadian culture textbooks, admits that she is unfamiliar with several items on Courchêne's cultural content list, demonstrating the variety and contradiction even within a cohort of highly educated, engaged EAL professionals. This disparity in knowledge points to the role that context and personal history can play in the choice and bias of materials presented to learners. Sauvé problematizes "knowing which version of culture to teach in which context and which to omit" (p. 22). Instead of a canon of knowledge-based materials that inevitably favor particular personal, regional, educational, gender, political, historical, and power biases, Sauvé advocates for "process curricula" (p. 19) that develop both teachers' and students' critical engagement with the particular contexts in which cultural acts take place. She wonders whether we should not "teach culture from a dynamic perspective that allows immigrant newcomers to value their own ways and make informed choices based on the knowledge of a number of different contexts in this country" (p. 21). 
Continuing the discussion of teaching culture in the TESL Canada Journal, Taylor (2001) also criticizes Courchêne's argument, stating that his "encyclopedic listmaking reinforces power relations of exclusion and normalization, and attempts to fix and totalize something that is dynamic and disrespectful of boundaries" (p. 72). She cautions against "reinforcing binaries of difference" (p. 72) and instead advocates exploring the journeys we have all made (student and teacher alike) in "forging a rich, diverse, and equitable society" (p. 74). Taylor does not reject outright Courchêne's four components of Canadian cultural content (history, shared values, voices, and traditions), but she adds and emphasizes "a vision in what we are becoming" (p. 74). This gives newcomers a participatory role with which they can more readily identify than the normative canon of content that lacks resonance with so many.

\section{Cultural Frameworks}

The participatory nature of cross-cultural analysis is what Kramsch (1993) proposes in situating selves within and outside native culture (C1) and target culture (C2), exploring the roles of cultural myths and realities in shaping personal identities and the perceptions of others. She states,

The only way to start building a more complete and less partial understanding of both $\mathrm{C} 1$ and $\mathrm{C} 2$ is to develop a third perspective, that would enable learners to take both an insider's and an outsider's view on $\mathrm{C} 1$ and $\mathrm{C} 2$. It is precisely that third place that cross-cultural education should seek to establish. (p. 210)

This "third place" is not manifest in Courchêne's work, but supports Sauvé's (1996) and Taylor's (2001) proposed "process curricula" whereby students engage critically in negotiating their understanding of Canadian culture and their ongoing role in it. These models not only move outside Courchêne's structured lists and frames of reference, but also illustrate Kramsch's (1993) claims that poststructuralist developments have exposed "how unreliable our very frames of reference are" (p. 224).

Atkinson (1999), on the other hand, analyzes the epistemology of culture represented in the past 15 years' worth of TESOL Quarterly articles, delineating the themes and theories of culture into three categories: (a) a stable, "received view" of culture; (b) a troubled or cautious take on the received view that falls back on it nonetheless; and (c) a view that rejects culture itself as a discussion point, preferring instead to use something more useful. Courchêne's view of Canadian culture neatly conforms to Atkinson's conservative "received view," where information is learned and transmitted formally.

To move the discussion forward, Atkinson (1999) uses studies and advances in anthropology and cultural studies to fill the gaps of culture studies in the TESL field, warning of the restrictive nature of normative received 
views and of the impossibility of impermeable, pure cultures that have not been altered by either internal or external influences. Sauvé's (1996) admission of not knowing all the items on Courchêne's cultural list demonstrates Atkinson's assertion that cultures cannot be pure and monolithic, but are "constantly recombining in new and unpredictable ways" (p. 633). Internal and external forces are continually reshaping cultures from inside and out, carrying some pieces of knowledge along with them as they move forward and leaving others behind. Courchêne acknowledges the shifts in Canada in terms of Judeo-Christian values that persist despite an increasingly secular world, but he adheres to "reintroducing" the history of certain Canadian institutions and laws in a historical context.

Far from rejecting the concept itself, Atkinson (1999) acknowledges the role that culture plays in our sense of identity. Atkinson proposes what he calls a "middle-ground approach to culture" (p. 636), drawing on sociocognitive theorists who describe a push-pull dance between people's ideas of culture ("in the head" or "inclinations") and the actions or manifestations of culture ("in the world" or "institutions," pp. 636-637). This approach recognizes the discursive relationship between what people believe, do, and witness in their cultural ways of being. It reduces the risk of disenfranchising participants new to a culture from being "othered" and made "wrong," and allows for ways that exhibited behaviors may not conform to stereotyped, codified norms. This is far better suited to a multicultural Canada where the norms may be as varied as the people who interact here, and it leads us to some exciting pedagogical practices.

\section{Alternative Pedagogical Approaches}

Although not specifically a response to Courchêne's, Sauvé's, and Taylor's articles, Ilieva (2001) has significantly advanced the discussion of teaching culture in her article where she proposes that students learn about Canadian culture by observing and discussing their observations of cultural acts for themselves. Ilieva's ethnographic observer's work offers a framework for examining interactions between people and for analyzing what occurred and what it meant. Instead of learning "cultural content," students acquire a tool that serves as a process of learning culture and its implications in various contexts. It enables the students to negotiate better the meaning of actions in various contexts and to "live effectively in a community" (p. 3). It satisfies Sauvé's (1996) call for the "making and remaking of relationships in our society" (p. 23) and Kramsch's (1993) steps toward cross-cultural understanding to "construct with the foreign learners their own context of reception" (p. 210).

To Ilieva's (2001) step-by-step process of naming, summarizing, relating, and determining the meaning of various observed behaviors, I would add predicting the expectations of what certain cultural values are and what behaviors might manifest before the observing fieldwork is done. The purpose 
of this preliminary step is for students to explore their own (C1) perceptions of the target culture (C2) and to recognize that they themselves have a position before they seek evidence of it. This step would facilitate further language practice in discussion before going out to observe interactions, and it moves students earlier toward their "third place."

This exploratory, reflective approach allows for developing the metatalk of cultural analysis that Kramsch (1993) advocates. It also lends itself better to a variety of situations, whether in varied social contexts with various power relations or to entirely different culture contexts. Where Courchêne (1996) and Sauvé (1996) may have had in mind more permanent newcomers to Canada for their work, Ilieva's (2001) expanded model can be extended to students who relocate to Canada for a limited study period and to those who simply realize the value in expanding their intercultural competence. It addresses Kumaravalivelu's (2006) major principles of particularity and possibility where a "true understanding of local linguistic, social, cultural and political particularities" allows students to engage critically in their new surroundings, and where students' "sociopolitical consciousness ... can ... function as a catalyst for identity formation and social transformation" (p. 69). This is relevant not only to immigrants to Canada, but to the myriad other learners and practitioners in the EAL field in Canada. The field consists of settlement-based language-learners, temporary international students, English-for-special-purposes (ESP) learners, as well as English-for-academicpreparation (EAP) students. Haneda (2002) describes Ilieva's approach as empowering in that it "offers the possibility for students to enact the mode of thinking nurtured in the classroom discussion in their future lives" (p. 93). Engaging in critical observation and reflection of cultural behaviors is well suited to any situation in which learners may find themselves. It is also well suited to teachers' professional practice.

\section{Implications for Professional Practice}

In reviewing the recent history and current state of teaching methodology, Kumaravalivelu (2006) delved into postmethod frameworks that have shifted to Task Based Language Teaching (TBLT), focusing on "curricular content rather than a methodological construct" (p. 65). Teaching culture, either through negotiated or less democratic means of delivery, qualifies as valid "curricular content." However, Ilieva's (2000) method of exploring culture further suits Kumaravalivelu's "learning-centered tasks ... engage[ing] the learner mainly in the negotiation, interpretation, and expression of meaning" (p. 65). It also involves learning for the teacher, who is no longer a detached expert in Canadian culture, but a participant who negotiates meaning alongside the learners. Haneda (2002) advocates for teachers' full participation in this negotiation, for 
It is only through critical reflection on their own cultural assumptions that teachers are in a position to provide empathetic support to students. To act as facilitators of the process, teachers themselves need to act as learners who explore culture together with their students in the classroom and with colleagues outside class. (p. 97)

The exploratory, portable, and expandable work proposed by Ilieva (2001) challenges not only the observation of cultural behaviors, but also what Pennycook (1989) referred to as "unequal power relationships," recognizing that "Second Language Education (SLE) is involved in a complex nexus of social, cultural, economic, and political relationships that involve students, teachers, and theorists in differential positions of power" (p. 590).

Classroom teachers have a significant role in presenting, cultivating, or critiquing a variety of power relationships in their teaching environments. Both the content and how it is studied carry political agendas. Pennycook asserts that perpetuating a received view of culture is a "(re)production of social and cultural inequalities ... and of particular forms of culture and knowledge" (pp. 590-591). Pennycook advocates for a critical examination of the interests being served by certain types of knowledge, a process that would reveal Courchêne's New Cultural Vision (1996) as normative and paternalistic.

\section{Implications for the Profession}

All this serves to disrupt some tried and true teaching traditions. It is easier to teach lists of cultural do's and don'ts than to deal with ambiguous realities, and negotiating meaning is not well suited to standardized curricula or testing. Sauvé (1996) calls for incorporating social, historical, economic, and critical elements into teacher education programs. Kramsch (1993) too advocates broadening language teachers' education, and Kumaravalivelu (2006) suggests that "a transformative teacher education program dovetails nicely with the ongoing shift from systematic discovery to critical discourse" (p. 74). With the vocational-style focus of so many TESL training programs, however, practicality tells us that this time-consuming critical discourse would take the place of other curricular content. Current TESL Canada (2006) teacher certification standards focus on the duration of teacher training, not the content of the curricula. Sauve (1996) articulates the common complaint that there are neither the funds nor the initiative to support ongoing professionalization and development of EAL professionals in Canada.

Perhaps some answers lie in teaching materials: not materials that "seem to hold a mainstream understanding of the concept of culture as a national attribute consisting of sets of values and behavior patterns" (Ilieva 2000, p. 60), or materials that take teachers by the hand and present a complete package for them simply to deliver. The danger in materials that are too teacher-friendly, however, is that they reduce the need for additional lesson 
preparation; that is, teachers do not need to prepare their own extension activities, which potentially lessens their agency in engaging with analyses of texts and bias. If questions are already prepared, there is no impetus to ask questions of one's own.

There is, however, a need for materials that guide teachers and learners in exploring culture together. Sauvé (1996) claims that teachers need enhanced skills to evaluate critically the appropriateness of materials for various learners; more open-ended questions, critical texts, oppositional teaching suggestions, and exploratory tasks would guide both new and practicing teachers to develop these skills as they use more discursive teaching materials.

The real promise, however, lies in the experience of teachers themselves. As students return to the classroom pleased or frustrated with the results of how their classroom knowledge has functioned in the real world (Fleming, 2003), teachers are obliged to assess the effects of their classroom practices. When colleagues come from all corners of the country and the world, they uncover the diversity of existing approaches, assumptions, and culture among us. We need to enable and explore these varied perspectives and valid contributions in their own right. We need to embrace the opportunity that ambiguity provides and to open ourselves to the inevitable shifts in culture and content in the classroom and the TESL profession. We need to revisit and invest in teachers as learners, facilitators of discovery, and one of the "innumerable forces" that keeps Canada's culture dynamic.

\section{The Author}

Jennifer Walsh Marr is a master's candidate in the Faculty of Education at Simon Fraser University, where the focus of her thesis research is on the identity formation and academic writing of multilingual undergraduate students. She is also researching university instructors' responses to the performance of students with English as an additional language (EAL) in writing-intensive courses. She has been teaching ESL and EFL since completing her BA in applied linguistics and Japanese studies at the University of Victoria in 1996.

\section{References}

Atkinson, D. (1999). TESOL and culture. TESOL Quarterly, 33, 625-654.

Courchêne, R. (1996). Teaching Canadian culture: Teacher preparation. TESL Canada Journal, 13, $1-16$.

Fleming, D. (2003). Building personal and nation-state identities: Research and practice. TESL Canada Journal, 20, 65-79.

Haneda, M. (2002). Learning culture through ethnographic inquiry: A response to Roumiana Ilieva "Living with ambiguity." TESL Canada Journal, 19, 92-97.

Hirsch, E.D. (1987). Cultural literacy: What every American needs to know. New York: Vintage. Ilieva, R. (2000). Exploring culture in texts designed for use in adult ESL classrooms. TESL Canada Journal, 17, 50-63.

Ilieva, R. (2001). Living with ambiguity: Toward culture exploration in adult second-language classrooms. TESL Canada Journal, 19, 1-16.

Kramsch, C. (1993). Context and culture in language teaching. Oxford, UK: Oxford University Press. 
Kumaravalivelu, B. (2006). TESOL methods: Changing tracks, challenging trends. TESOL Quarterly, 40, 59-81.

Morasse, C. 1995). La composante culturelle en enseignement des langues seconds. Unpublished paper, Faculty of Education, University of Ottawa.

Pennycook, A. (1989). The concept of method, interested knowledge, and the politics of language teaching. TESOL Quarterly, 23, 589-618.

Sauvé, V. (1996). Working with the cultures of Canada in the ESL classroom: A response to Robert Courchêne. TESL Canada Journal, 13, 17-23.

Sauvé, V. (1997). Gateway to Canada. Toronto, ON: Oxford University Press.

Taylor, L. (2001). "Canadian Culture," cultural difference, and ESL pedagogy: A response to Robert Courchêne and Virginia Sauvé. TESL Canada Journal, 15, 70-76.

TESL Canada Certification Standards. (n.d.). Available:

http:/ / www.tesl.ca/Asset51.aspx?method=1 